\title{
Status of kinases in Epstein-Barr virus and Helicobacter pylori Coinfection in gastric Cancer cells
}

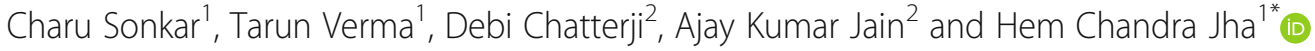

\begin{abstract}
Background: Helicobacter pylori (H. pylori) and Epstein - Barr virus (EBV) plays a significant role in aggressive gastric cancer (GC). The investigation of genes associated with these pathogens and host kinases may be essential to understand the early and dynamic progression of GC.

Aim: The study aimed to demonstrate the coinfection of EBV and $\boldsymbol{H}$. pylori in the AGS cells through morphological changes, expression of the kinase and the probable apoptotic pathways.

Methods: Genomic DNA isolation of H. pylori and its characterization from clinical samples were performed. RTqPCR of kinases was applied to scrutinize the gene expression of kinases in co-infected GC in a direct and indirect (separated through insert size $0.45 \mu \mathrm{m}$ ) H. pylori infection set up. Morphological changes in co-infected GC were quantified by measuring the tapering ends of gastric epithelial cells. Gene expression profiling of apoptotic genes was assessed through RT-qPCR.

Results: An interleukin-2-inducible T-cell kinase (ITK) showed significant upregulation with indirect H. pylori infection. Moreover, Ephrin type-B receptor six precursors (EPHB6) and Tyrosine-protein kinase Fyn (FYN) showed significant upregulation with direct coinfection. The tapering ends in AGS cells were found to be extended after 12 h. A total of 24 kinase genes were selected, out of which EPHB6, ITK, FYN, and TYK2 showed high expression as early as $12 \mathrm{~h}$. These kinases may lead to rapid morphological changes in co-infected gastric cells. Likewise, apoptotic gene expression such as APAF-1 and Bcl2 family genes such as BAD, BID, BIK, BIM, BAX, AND BAK were significantly down-regulated in co-infected AGS cells.

Conclusion: All the experiments were performed with novel isolates of $H$. pylori isolated from central India, for the functional assessment of GC. The effect of coinfection with EBV was more profoundly observed on morphological changes in AGS cells at $12 \mathrm{~h}$ as quantified by measuring the tapering of ends. This study also identifies the kinase and apoptotic genes modulated in co-infected cells, through direct and indirect approaches. We report that ITK, EPHB6, TYK2, FYN kinase are enhanced, whereas apoptotic genes such as APAF-1, BIK, FASL, BAX are significantly down-regulated in AGS cells coinfected with EBV and H. pylori.
\end{abstract}

Keywords: Gastric cancer, Helicobacter pylori, Epstein Barr virus, Interleukin-2-inducible T-cell kinase, Tyrosine-protein kinase Fyn, Adenocarcinoma gastric cell

\footnotetext{
* Correspondence: hemcjha@iiti.ac.in

${ }^{1}$ The Discipline of Biosciences and Biomedical Engineering, Indian Institute of Technology Indore, Room no. 302, School Building, IIT Indore, Khandwa Road, Simrol, Indore 453552, India

Full list of author information is available at the end of the article
}

(C) The Author(s). 2020 Open Access This article is licensed under a Creative Commons Attribution 4.0 International License, which permits use, sharing, adaptation, distribution and reproduction in any medium or format, as long as you give appropriate credit to the original author(s) and the source, provide a link to the Creative Commons licence, and indicate if changes were made. The images or other third party material in this article are included in the article's Creative Commons licence, unless indicated otherwise in a credit line to the material. If material is not included in the article's Creative Commons licence and your intended use is not permitted by statutory regulation or exceeds the permitted use, you will need to obtain permission directly from the copyright holder. To view a copy of this licence, visit http://creativecommons.org/licenses/by/4.0/. The Creative Commons Public Domain Dedication waiver (http://creativecommons.org/publicdomain/zero/1.0/) applies to the data made available in this article, unless otherwise stated in a credit line to the data. 


\section{Background}

Cancer is the second leading cause of death globally and was responsible for an estimated 960,000 deaths in 2018. Globally, about 1 in 6 deaths occur due to cancer with gastric cancer (GC) being the third leading cause of cancer-related deaths. Despite primary management which consists of surgical resection followed by radiation therapy and chemotherapy, it is poorly prognosticated [1]. The delay in the detection of GC leads to frequent relapse and metastasis. Hence, it is imperative to find the serendipitous prognostic markers, which may be helpful in early diagnosis of GC.

The crucial link between GC and $H$. pylori is well established [2]. The H. pylori are considered a type I carcinogen in GC [3]. H. pylori is prevalent across the globe with significantly higher incidence seen in the eastern part of Asia, such as Japan and Korea [4]. H. pylori shows a high level of intra-species genetic diversity where strain-specific features are critical for progression of GC [4]. If $H$. pylori infection remains untreated, it colonizes the stomach and can persevere lifelong. The driving factors which turn $H$. pylori into pathogenic bacteria are poorly known. Kinases play a role as pivotal regulators in epigenetic modulation in various diseases, including cancer [5]. Recent studies suggested that $H$. pylori infection leads to the up-regulation of tyrosine kinase, MAPK cascade, PDK1, AKT3, SRC, FYN, YES, and mTOR, and dysregulation of non-receptor tyrosine kinase in cancer progression [6-9].

The viral coded protein can also cause tumorigenesis, which is derived from the transformation of the temperature-sensitive mutation of the virus [10]. Limited reports are available related to the molecular mechanism of virus mediated tumorigenesis [11]. The involvement of kinases, bacteria, and viruses in different types of cancers has been sequentially investigated for the development of cancer therapy. The protein kinase association with $\mathrm{v}$-Src in-vitro was a breakthrough in the field of cancer biology [11]. Several reports suggest the association of Rous sarcoma virus with protein kinase activity related to the cancer disease [12]. Interestingly, kinases are considered as a potential target in cancer therapy.

Finally, the discovery of EBV, the first human virus associated with cancer, clearly showed the oncogenic potential of microorganisms [13]. Most of the human cancers (15-20\%) are associated with a viral infection, and EBV is recognized as one of the contributors in GC (9\% of all GC) [14]. The exact mechanism of EBV as an oncogenic agent in GC is poorly understood. The EBV is associated with several lymphoid and epithelial cancers and is considered as an active oncogenic agent in GC progression [15]. In the EBV associated GC, host genes such as JAK2, MET, FGFR2, BRAF, RAF, EPHA4, PAK1, PAK2, EPHB6, ERBB4, ERBB2, and ITK are up- regulated [16-22]. In contrast, FGFR4 and ROR2 genes are down-regulated in GC $[23,24]$. In Asian countries, the incidence of EBV positive person developing GC are rapidly increasing (6-10\% approximately). Moreover, western and central Asian countries have a considerably higher frequency of EBV positive cases [25]. Another challenging aspect is the coinfection of EBV with $H$. pylori that has been reported to cause aggressive GC [26]. Thereby, it is imperative to develop a coinfection model for investigating the progression of $\mathrm{GC}$, which can be used to test the potential role of protein kinases, which is one of the hallmarks in all cancers.

To the best of our knowledge, this is the first report that shows the association of EBV and H. pylori (coinfection model) in GC through kinase protein. In view of above, the present study was conducted with following objectives: (1) To demonstrate the coinfection of EBV and $H$. pylori in AGS cell line for GC progression, (2) To determine the morphological changes after coinfection, (3) To evaluate the expression of the kinases in coinfection and; (4) To study the probable apoptotic pathway involved in the co-infected GC.

\section{Methods}

Animal cell cultures and $H$. pylori cultures

Adenocarcinoma gastric (AGS) cell line was procured from National Centre for Cell Science (NCCS), Pune, India. The cells were grown in Dulbecco's modified Eagle's medium (DMEM; Himedia, Mumbai, India) supplemented with $10 \%$ fetal bovine serum (FBS; BIOWEST, South America origin), $1 \%$ penicillin-streptomycin (Himedia, Mumbai, India). Infectious EBV was produced by transfection of BAC-EBV-GFPWT into HEK-293 T (human embryonic kidney cell) cells, selection followed by chemical induction. We received the transfected HEK293T EBV BAC as gift from University of Pennsylvania, USA, which were further cultured in the lab. Cultured HEK $293 \mathrm{~T}$ EBV BAC were induced for 5 days with $20 \mathrm{ng} / \mathrm{ml}$ tetradecanoyl phorbol acetate (TPA) and $3 \mathrm{mM}$ butyric acid (Sigma-Aldrich Corp., St. Louis, $\mathrm{MO})$. The supernatant from cell culture was collected and treated with DNAse. The viruses were concentrated by ultracentrifugation $23,500 \times \mathrm{g}$ at $4{ }^{\circ} \mathrm{C}$ for $1 \mathrm{~h} 30 \mathrm{~min}$ and quantified through qRT-PCR [27-29]. The infective dose of EBV was determined by infecting $25 \times 10^{4}$ AGS cells seeded in 6 well plates with $0,25,50,75,100$, and $125 \mu \mathrm{l}$ of the isolated virus. It was followed by isolation of mRNA, preparation of cDNA, and RT-qPCR for detection of EBNA-1. EBNA1 oncoprotein is the only viral protein expressed in all forms of latency during EBV infection [30]. We confirmed the presence of EBV in the AGS cells through RT-qPCR. RT-qPCR is a recognized method for determining multiplicity of infection which has been used in other studies as well, and thus we used 
this method to determine the titer value [31, 32]. We found that the infective dose resulting in high expression of EBNA-1 was $100 \mu \mathrm{l}$ which corresponds to $20 \mathrm{MOI}$ [33, 34]. The H. pylori strain I10 was kindly provided by Dr. Asish Kumar Mukhopadhyay (National Institute of Cholera and Enteric Diseases, ICMR, Kolkata, India). The reference strain $\mathrm{I} 10$ has also been used and reported in one of our previous studies [35]. The biopsy sample and gastric juice were provided by Dr. Ajay Kumar Jain (gastroenterologist), Choithram Hospital and Research Centre, Madhya Pradesh, India. Cell culture experiments were performed at $37{ }^{\circ} \mathrm{C}$ in a humidified environment supplemented with $5 \% \mathrm{CO}_{2}$. The $H$. pylori strains were grown in Whitley DG250 Anaerobic Workstation at $37^{\circ} \mathrm{C}$ with micro-aerophilic conditions (85\% $\mathrm{N}_{2}, 10 \%$ $\mathrm{CO}_{2}$, and $5 \% \mathrm{O}_{2}$ ).

\section{Isolation and identification of $\boldsymbol{H}$. pylori}

The rapid urease test kit (CLO Test Ballard Medical Products, Draper, UT, USA) was used on gastric biopsy samples to check the presence of $H$. pylori. Gastric juices were also obtained from RUT positive patients. The tissue homogenate was prepared by crushing the biopsy samples. A loop-full of tissue homogenate was cultured on a non-selective medium such as Brain Heart Infusion media (BD-DIFCO, USA). This media was supplemented with $H$. pylori selective antibiotics such as vancomycin, cefsulodin, amphotericin, and trimethoprim with 10, 5, 5 , and $5 \mathrm{mg} / \mathrm{L}$, respectively (Sigma Aldrich, St Louis, MO, USA). These plates were incubated in a microaerophilic environment for 3-5 days. A point sized colony was identified and used for the Gram staining. The colony was screened through morphological similarities with $H$. pylori. The samples were human gastric biopsy and gastric juice; thus, they were named $\mathrm{HB}$ and $\mathrm{HJ}$, respectively, followed by a numeral that denotes the patient number according to the sequence of sample collection.

Further, $H$. pylori were confirmed by polymerase chain reaction (PCR) for $16 \mathrm{~S}$ rRNA gene. For the present study, two clinically isolated bacterial strains were considered; HB1 (human biopsy sample\#1), HJ9 (Human gastric juice sample\#9), and one reference strain I10. The $H$. pylori bacteria were grown in selective media in a $14 \mathrm{ml}$ round bottom snap cap tube $(14 \mathrm{ml}$ round bottom snap cap tube (BD Biosciences, Franklin Lakes, NJ, USA - Catalogue No. 352001). They were then incubated in the microaerophilic chamber for $72 \mathrm{~h}$. Subsequently, $150 \mu \mathrm{l}$ of grown culture was placed in duplicate in 96 well flat-bottom plates, and optical density (OD) was recorded at $600 \mathrm{~nm}$ (Synergy H1 Hybrid MultiMode Reader, BioTek). An optical density of 0.3 at 600 $\mathrm{nm}$ represents 500 million CFU/ $\mathrm{mL}$ [36]. The final OD value was normalized with media as a negative control
$[35,37]$. The number of bacterial cells per $\mathrm{ml}(\mathrm{CFU} / \mathrm{mL})$ of culture was evaluated according to the final OD, and the required volume of the bacterial culture for infection was then calculated.

\section{Cell proliferation measurement}

$25 \times 10^{4}$ AGS cells were infected with $H$. pylori isolate I10, HB1, and HJ9 at MOI 100 and incubated at $37{ }^{\circ} \mathrm{C}$ for 6-8 h, subsequently further infected with EBV at an infective dose of $100 \mu \mathrm{L}$. The AGS cells were infected with EBV, EBV-I10, EBV-HB1, and EBV-HJ9, respectively. Uninfected AGS cells were used as control. The cells were trypsinized and diluted with trypan blue (1:1). The cells were counted through hemocytometer at 6,12 , 24 , and $36 \mathrm{~h}$, respectively, with white cells being viable and blue depicting non-viable cells [26]. The morphological changes in the cells were evaluated by DAPI staining. The confocal laser scanning microscopy (CLSM) was performed using Multi-photon laser (FV1200MPE, IX83 Model, Olympus). The ImageJ software was used for the cell length measurements. All the statistical data was analyzed by GraphPad Prism software.

\section{Coinfection of EBV and $H$. pylori}

AGS cells $\left(25 \times 10^{4}\right)$ were seeded in 6 well plates followed by $H$. pylori infection through transwell inserts of $0.45 \mu \mathrm{m}$ at MOI of 100 . After $6-8 \mathrm{~h}$, transwell were removed, and the cells were infected with EBV at an infective dose of $100 \mu \mathrm{l}$. This was followed by centrifugation at $2000 \mathrm{rpm}$ for $20 \mathrm{~min}$ followed by re-insertion of transwell insert. This setup was then incubated for various time intervals. For the direct infection approach, the rest of the protocol remained the same without the use of a transwell. The graphical representation of the experiments performed in the project is shown in Fig. 1, which depicts the procedure of direct and indirect coinfection in the cells, which were followed by other experiments like RT-qPCR. After 12, 24, and $36 \mathrm{~h}$, cells were scrapped through cell lifter and centrifuged at $3000 \mathrm{rpm}$ for $5 \mathrm{~min}$ to get the pellet. This pellet was washed with phosphate buffer saline (PBS; pH 7.4; $10 \mathrm{mM}$ ) twice and stored at $-20^{\circ} \mathrm{C}$ till further use.

\section{Quantitative RT-PCR}

The cells were infected with the bacteria followed by virus incubation for 12 and $24 \mathrm{~h}$, respectively. The Trizol reagent was used for RNA extraction from co-infected cells. The isolated RNA $(0.5 \mu \mathrm{g})$ was used to synthesize the cDNA with the help of the Takara cDNA synthesis kit. The primers for kinase genes are listed in (Table 1), subsequently primers for apoptotic genes and for $H$. pylori are mentioned in (Table 2). The thermocycler conditions used for the real-time PCR (RT-qPCR) were for 40 


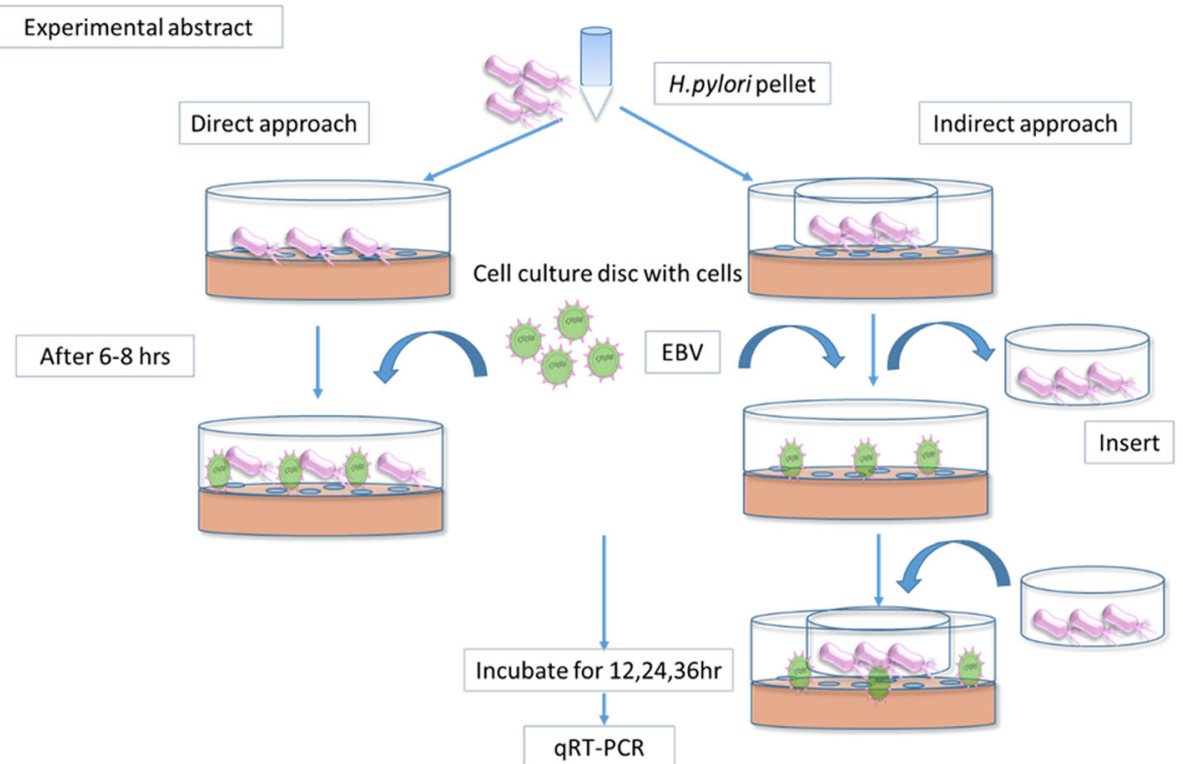

Fig. 1 Schematic representation of the experimental setup performed in the report. Two approaches used for an experiment wherein Direct approach $H$. pylori was added to cells at $\mathrm{MOI} 100$ without an insert. After 6-8 h, these cells were infected with EBV. Whereas in the Indirect approach, H. pylori-infected the cultured cells through an insert. Again after 6-8 h insert was removed, cells were infected with EBV, and again, the insert containing bacteria resumed in its original position

cycles and set at $94{ }^{\circ} \mathrm{C}$ for $15 \mathrm{~s}, 54^{\circ} \mathrm{C}$ for $20 \mathrm{~s}$, and $72{ }^{\circ} \mathrm{C}$ for $20 \mathrm{~s}$, respectively, using SYBR green. The expression analysis was carried out using $2^{-\Delta \Delta t}$ method.

\section{Statistical analysis}

The analysis and quantification of the experimental setup were done through Image J and Graph Pad Prism software version 6, respectively. Biological triplicate was required for each experiment. Quantitative data were shown as mean $\pm \mathrm{SD}$. The difference comparison between groups was analyzed with independent $\mathrm{t}$-test or ANOVA. In all analyses, $p<0.05$ was seen as a significant level.

\section{Results}

\section{Isolation and characterization of $H$. pylori isolates}

We have successfully extracted five isolates of $H$. pylori from gastric biopsy and gastric juices, namely, HB1, HB10, HJ1, HJ9, and HB14, which was followed by Gram staining, where I10 was used as reference strain (Fig. S1). Genomic DNA isolation was performed and 16sRNA primer was used for the screening of the bacteria along with reference strain (Fig. S2). Among the five isolates, two isolates were selected for further experiments. The reference strain I10, along with two isolated strains of the H. pylori isolates HB1 and HJ9, were used for further experiments. The PCR was performed using H. pylori strains' genomic DNA as template to amplify $16 \mathrm{~s}$ rRNA genes, with a product size of $110 \mathrm{bp}$ (Fig. S3).

\section{H. pylori and EBV coinfection leads to morphological changes}

Previous studies have shown that morphological and phenotypic changes can be detected in virus-infected cells [38]. These cells acquire a characteristic elongated cell shape with an invasive phenotype that contributes to tumor invasion and metastasis [39]. Our data shows that similar morphological changes such as elongated tapering ends were observed in AGS infected H. pylori at $24 \mathrm{~h}$ [40]. Our results show that tapering ends of co-infected cells were found to be more elongated as compared to those seen in uninfected cells (Fig. 2a, S4). Interestingly, the co-infected AGS showed morphological changes even after $12 \mathrm{~h}$ of incubation, which may reflect the positive synergistic effect of EBV and $H$. pylori in cell proliferation.

The elongations in tapering ends were quantified by confocal laser scanning microscopy using DAPI stain at various time intervals such as $12,24,36$, and $48 \mathrm{~h}$, respectively (Fig. S5). The analysis and quantification of the experimental setup were done through Image $J$ and Graph Pad Prism software, respectively (Fig. 2b). Our results asseverate that the maximum length projection appears at $12 \mathrm{~h}$ post-infection (Fig. S6). The lengths of the sharp end of co-infected cells were measured to estimate the effect of EBV on AGS cells at $12 \mathrm{~h}$ incubation. Our data shows that approximately 10 fold increase in the tapering end length was observed in comparison with the control, which suggests that EBV has a positive effect on cell growth and migration (Fig. 2b). 
Table 1 list of primers used with their primer sequences

\begin{tabular}{|c|c|c|c|}
\hline S.No. & Gene name & Forward primer & Reverse primer \\
\hline 1. & EPHB6 & ATGAAGTGCCCTCTGCTGTC & CTGCCTGGTCATAGTAGCGG \\
\hline 2. & MAPK1 & AACAGGCCCATCTITCCAGG & CCAGAGCTITGGAGTCAGCA \\
\hline 3. & SRC & ACATCCCCAGCAACTACGTG & CAGTAGGCACCTTTCGTGGT \\
\hline 4. & AKT3 & ACCGCACACGTTTCTATGGT & TTCATGGTGGCTGCATCTGT \\
\hline 5. & JAK2 & TGGGGTTTCTGGTGCCTTT & TAGAGGGTCATACCGGCACA \\
\hline 6. & PAK1 & ACAGGAGGTGGCCATTAAGC & CACAGCTGCAATTTGGCCTT \\
\hline 7. & PAK2 & ATTGGACAAGGGGCTTCTGG & CCACATCAGTGAGTGACCCC \\
\hline 8. & ERBB2 & CGCTGAACAATACCACCCCT & GCCAGCTGGTTGTTCTTGTG \\
\hline 9. & FGFR2 & CCAACTGCACCAACGAACTG & ACTGTTCGAGAGGTTGGCTG \\
\hline 10. & METMET & GTCCTGCAGTCAATGCCTCT & GTCAGCCTTGTCCCTCCTTC \\
\hline 11. & PDK1 & AAGTTCATGTCACGCTGGGT & GCATCTGTCCCGTAACCCTC \\
\hline 12. & ROR2 & ACGTACGCATGGAACTGTGT & CGGCACATGCAAACCAAGAA \\
\hline 13. & ERBB4 & ACAGGGGGCAAACAGTTCA & AGCCCACCAATTACTCCAGC \\
\hline 14. & FYN & CTCAGCACTACCCCAGCTTC & AGGTCCCCGTATGAGACGAA \\
\hline 15. & ITK & ATTATCTACGCACCCAGCGG & ATGCCCTCACACACATCCAG \\
\hline 16. & TYK2 & CCCATGGCTTGGAAGATGGT & ACTCAGCTTGATGAAGGGGC \\
\hline 17. & YES 1 & GCTCCTGAAGCTGCACTGTA & GCATCCTGTATCCTCGCTCC \\
\hline 18. & EPHA4 & AAGGCTATCGGTTACCCCCT & CTTCAAGCTGTTGGGGTTGC \\
\hline 19. & MERTK & GCCCCATCAGTAGCACCTTT & TGCACGTAGCATTGTGGACT \\
\hline 20. & TYRO3 & CAAACTGCCTGTCAAGTGGC & CCCGCCAATGAGGTAGTTGT \\
\hline 21. & BRAF & AGAGGCGTCCTTAGCAGAGA & ATCGGTCTCGTTGCCCAAAT \\
\hline 22. & MTOR & TCGCTGAAGTCACACAGACC & CTTTGGCATATGCTCGGCAC \\
\hline 23. & RAF1 & AATCAGCCTCACCTTCAGCC & AAAGAGCCTGACCCAATCCG \\
\hline 24. & FGFR4 & GAGTCTCGTGATGGAGAGCG & AGTTATAGCGGATGCTGCCC \\
\hline
\end{tabular}

\section{Effect of coinfection on cell proliferation}

Previous studies have suggested that EBV and $H$. pylori both may promote cell proliferation through inducing morphological changes $[41,42]$. At $12 \mathrm{~h}$ the cell proliferation assay shows a decrease in cell number when cells were infected with EBV alone. However, an increase in cell proliferation is observed when EBV infection is followed by a bacterial infection (Fig. 3). Hence, our finding suggests that bacteria may provide positive thrust for cell proliferation. In comparison with control, the cells co-infected with HJ9 showed an approximately 2 fold increase in cell proliferation at $12 \mathrm{~h}$. However, in HB1 co-infected cells, no significant change in proliferation was observed till $24 \mathrm{~h}$. The positive effect of bacterial co-infection on the growth of cells is strain dependent, and it can affect the proliferation in a time-dependent manner. Interestingly, the cell number increases significantly when AGS cells infected with EBV alone or co-infected with $H$. pylori and EBV, when compared to un-infected AGS cells.
Assessment of kinase expression through a secretory and adhesive mechanism of bacteria

To evaluate differential expressions of several kinases, both direct and indirect infection methods were used [27]. In the indirect approach, the effect of proteins secreted from bacteria was assessed; and in the direct approach the kinases that are mostly affected by adherence were evaluated. Here, we tried to investigate the kinases of secretory and adherence pathways of $H$. pylori to get an insight into the underlying strategy which involves the cooperation of $H$. pylori in EBVdriven proliferation of gastric epithelial cells. Hence, already developed $H$. pylori and EBV coinfection model was used for AGS human gastric epithelial cells. This model would give us access to investigate the effect of molecules secreted by $H$. pylori. Hence we used the $0.45 \mu \mathrm{m}$ insert, which has been used for a similar purpose in the previous reports [27, 43]. As the effect of adherence of $H$. pylori to gastric mucosa through CagA is linked to the severity of gastritis, it was intriguing to compare the effect of secretory 
Table $\mathbf{2}$ List of primers for apoptotic genes

\begin{tabular}{|c|c|c|c|}
\hline S.No. & Gene name & Forward Primer & Reverse Primer \\
\hline 1. & PARP1 & GGCGATCTTGGACCGAGTAG & AGCTTCCCGAGAGTCAGGAT \\
\hline 2. & APAF1 & CTTGCTGCCCTTCTCCATGA & TTGCGAAGCATCAGAATGCG \\
\hline 3. & FASR & CCTGCCAAGAAGGGAAGGAG & TTTGGTGCAAGGGTCACAGT \\
\hline 4. & BID & CTGCAGGCCTACCCTAGAGA & GTGTGACTGGCCACCTTCTT \\
\hline 5. & BIK & ACCTGGACCCTATGGAGGAC & CTGAGGCTCACGTCCATCTC \\
\hline 6. & BIM & СTTCCATGAGGCAGGATGAA & TCCAATACGCCGCAACYCYY \\
\hline 7. & BAX & CATGGGCTGGACATTGGACT & AAAGATGGTCACGGTCTGCC \\
\hline 8. & NOXA & CAAGAACGCTCAACCGAGCC & GCCGGAAGTTCAGTTTGTCTC \\
\hline 9. & FAS & GGACCCTCCTACCTCTGGTT & GCCACCCCAAGTTAGATCTGG \\
\hline 10. & FADD & CACCAAGATCGACAGCATCG & AGATTCTCAGTGACTCCCGC \\
\hline 11. & BAK & GGTTITCCGCAGCTACGTT & TAGCGTCGGTTGATGTCGTC \\
\hline 12. & CASPAS9 & TGCTCAGACCAGAGATTCGC & TCTTTCTGCTCGACATCACCAA \\
\hline 13. & 16s RNA (H.pylori) & CTGGAGAGACTAAGCCCTCC & ATTACTGACGCTGATTGCGC \\
\hline
\end{tabular}

proteins and adherence of bacteria in gastric cells infected with EBV [44-46].

All 24 kinases were screened based on their presence in GC either infected with $H$. pylori or EBV alone. Their gene expressions were evaluated at a time interval of 12 , 24 , and $36 \mathrm{~h}$, respectively. Out of 24 genes, eight genes showed considerable changes in gene expression, which are BRAF1, ITK, TYK2, FYN, PAK1, PAK2, PDK1, and EPHB6. Among the eight genes, four genes showed significant changes in expression, which were ITK, FYN, TYK2, and EPHB6. Reports suggest a high expression of ITK, FYN, and TYK2 in GC, whereas EPHB6 showed reduced expression in GC $[47,48]$. According to our experimental data, TYK2 and EPHB6 transcripts were enhanced by the indirect coinfection approach, whereas the other two genes, like FYN and ITK, were observed to be up-regulated in the direct coinfection approach (Fig. 4).

In the direct approach at $12 \mathrm{~h}$ incubation, ITK was found to be significantly down-regulated in AGS cells co-infected with EBV-I10, EBV-HB1, and EBV-HJ9 compared to controls at $12 \mathrm{~h}$ time point. Interestingly, ITK was slightly down-regulated in AGS-EBV compared to control AGS cells. However, there is a slight downregulation of the ITK gene in AGS-EBV infected cells in comparison with AGS (Fig. 4A.1). Additionally, the FYN gene transcript showed non-significant changes in AGSEBV and EBV-I10. However, FYN levels were considerably up-regulated in EBV-HB1 and EBV-HJ9 (Fig. 4A.2). Noticeably, FYN expression was 2.5-fold higher. Hence, in comparison to AGS within EBV-I10, EBV-HB1 and EBV-HJ9 showed about 2.5-fold increases in expression in FYN when compared to controls. Further, the TYK2 gene transcript showed down-regulation in AGS-EBV and EBV-HB1 while showed enhanced up-regulation in
EBV-I10 and EBV-HJ9 (Fig. 4A.3). The EPHB6 gene transcript showed more than 6-fold was up-regulated by AGS-EBV and EBV-HB1, while, coinfection group such as EBV-I10 and EBV-HJ9 showed more than 2.5-fold and 10-fold enhanced expression, respectively (Fig. 4A.4). Therefore, based on the gene expression profiling, it is clear that TYK2 and EPHB6 may have a pivotal role in early prognosis and pathway determination.

Furthermore, at $24 \mathrm{~h}$ time point, ITK expression does not vary significantly in AGS-EBV and EBV-HB1, while considerable down-regulation was observed showing a mild and significant decrease in expression in EBV-I10 and EBV-HJ9, respectively (Fig. S7.1). However, FYN expression showed a 2.5 to a 60,000 -fold increase in expression of AGS-EBV and EBV-HJ9, respectively. Additionally, EBV-HB1 showed a slight increase in expression, whereas EBV-I10 showed no remarkable changes in gene expression in comparison to AGS (Fig. S7.2). The TYK2 expression was significantly reduced in both EBV-I10 and EBV-HJ9 while showing no noticeable changes in AGS-EBV and EBV-HB1 (Fig. S7.3). The EPHB6 expression level was found to be detected mildly and significantly less in EBV-HB1 and EBV-HJ9, respectively, while no changes were observed in the expression of EPHB6 in AGS-EBV and EBV-I10 respectively (Fig. S7.4). Importantly, there were no significant changes observed at $36 \mathrm{~h}$ in these cells (Fig. S8).

In the indirect approach at $12 \mathrm{~h}$, ITK and FYN expression were significantly increased from about 6-10 fold and 10-50 folds in EBV-I10 and EBV-HJ9, respectively (Fig. 4B.1, B.2). In comparison, these genes showed no significant changes in AGS-EBV and EBVI10. However, the TYK2 gene showed a significant decrease in the expression of EBV-HJ9 and EBV-HB1, while no considerable changes were observed in AGS- 


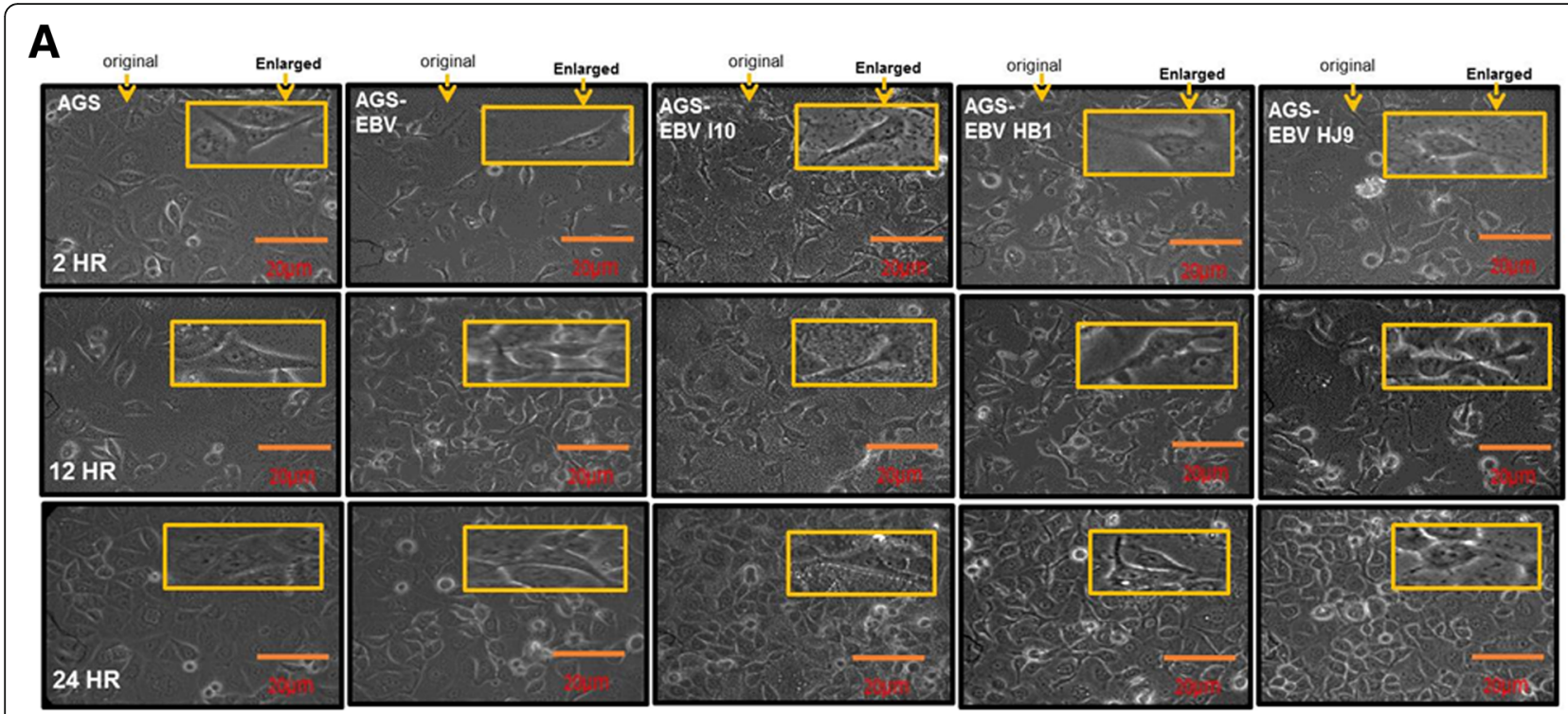

B

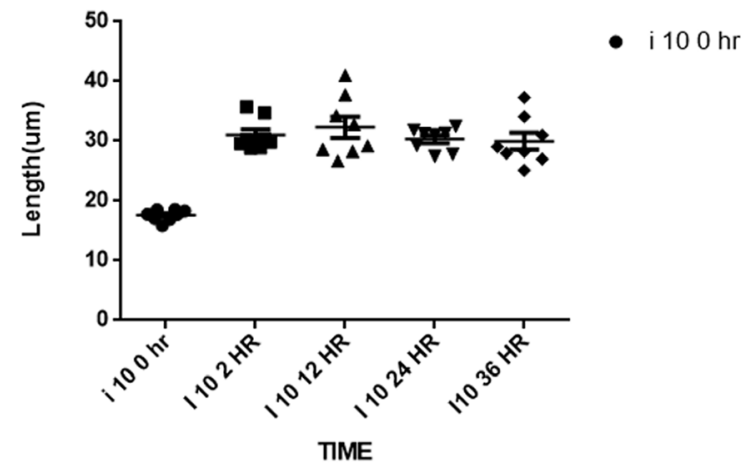

I10 time dependent

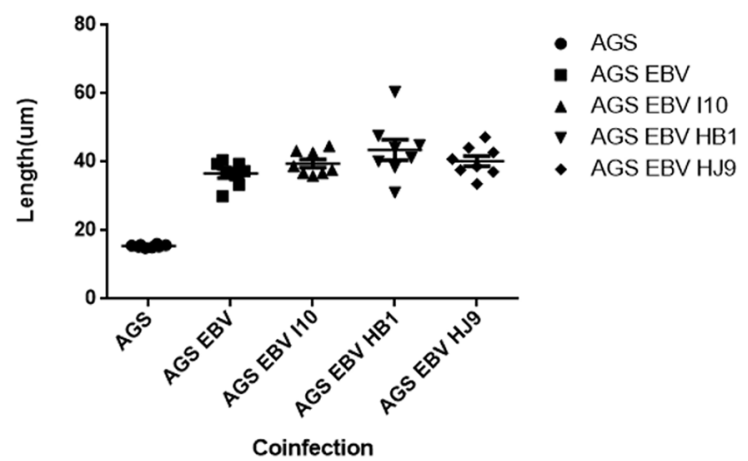

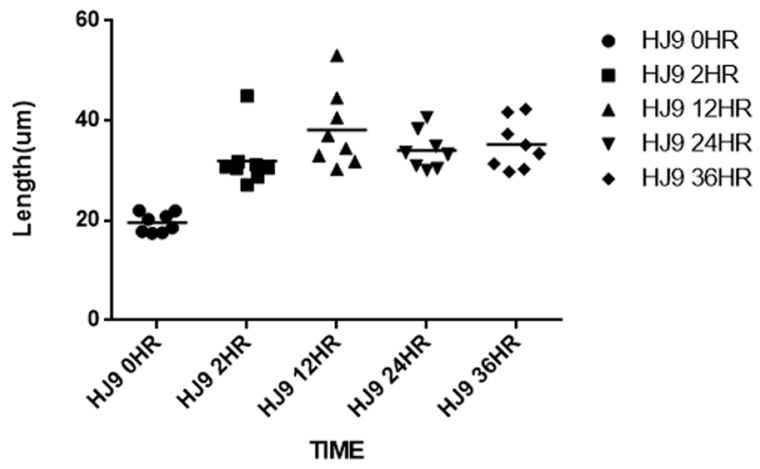

HJ9 Time dependent

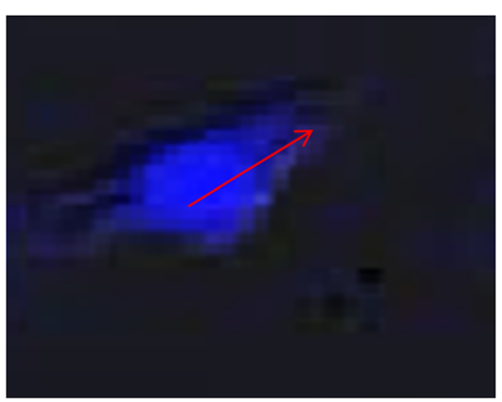

\section{Coinfection at $12 \mathrm{hr}$}

Fig. 2 H. pylori and EBV coinfection lead to morphological changes. a AGS cells were infected with EBV, and then AGS cells were infected with EBV and H. pylori I10, HB1, HJ9, respectively. Changes in the number of cells and morphological changes were observed at $2 \mathrm{~h}, 12 \mathrm{~h}$, and $24 \mathrm{~h}$ where insert image shows the enlarged image of morphological changes. b Quantification of extended length was done for all experiments through Graph Pad Prism software. The single-cell DAPI stained picture of the cell determines the way the cell length is measured through the software. The arrow depicts the measurement of the cell length 


\section{CELL PROLIFERATION ASSAY}

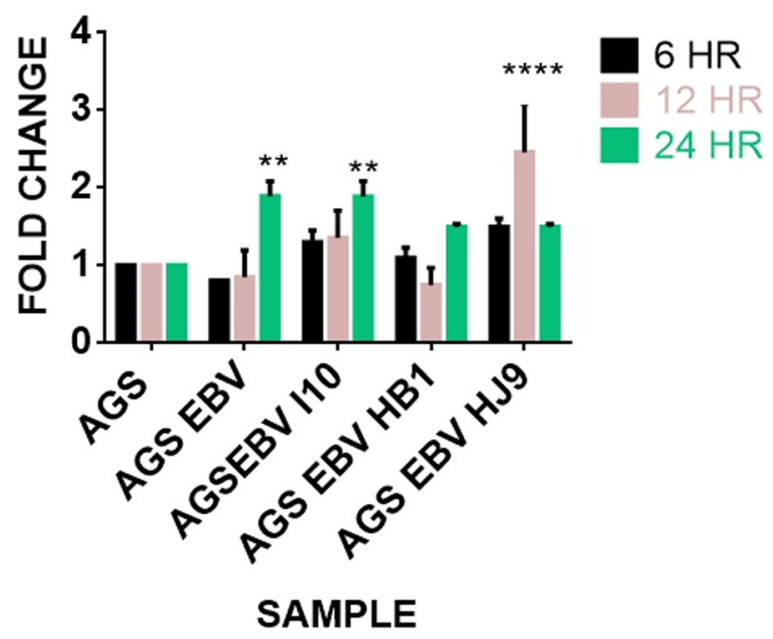

Fig. 3 Effect of coinfection in cell proliferation. Cell proliferation of AGS when treated with EBV and AGS-EBV with different strains of bacteria I10, HB1, and HJ9, respectively, at different time points of 6 , 12 , and $24 \mathrm{~h}$

EBV and EBV-I10 (Fig. 4B.3). The EPHB6 gene transcript showed a more than 10fold increase in AGSEBV and EBV-HJ9, and more than 6 fold increases in EBV-I10 and EBV-HB1 (Fig. 4B.4). ITK gene expression at $24 \mathrm{~h}$ showed more than 10,000 to 50,000 fold increase in EBV-HB1 and AGS-EBV, respectively, whereas 20 fold increase is observed in EBV-HJ9 (Fig. S9.1). In the FYN gene, no significant changes were observed in AGS-EBV, while more than 2.5, 10, and 20 fold increase in expression were observed in EBVHJ9, EBV-I10, and EBV-HJ9, respectively (Fig. S9.2). The TYK2 gene expression decreased mildly, in AGSEBV, and no changes were found in EBV-I10, while a significant increase is observed in EBV-HB1 and EBVHJ9 (Fig. S9.3). EPHB6 gene showed approx. 20 fold increase in the expression in of AGS-EBV and approx. 2.5 fold increase in EBV- HJ9, EBV-I10, and EBV-HB1, respectively (Fig. S9.4). In $36 \mathrm{~h}$, the ITK gene showed more than 6, 10, 250 fold increase in AGS-EBV, EBV-I10, EBV-HB1, respectively, and a significant decrease in EBV-HJ9 (Fig. S10.1). The FYN gene transcript showed 17,000, 20, 250, 4 fold increased expression in AGS-EBV, EBV-I10, EBV-HB1, and EBV-HJ9, respectively (Fig. S10.2). The TYK2 gene showed no significant changes in any sample (Fig. S10.3). EPHB6 gene showed an increase in expression of the transcript, with $6,17,28$, and 30 fold in AGS-EBV, EBV-10, EBV-HB1, and EBV-HJ9, respectively (Fig. S10.4). Hence, our findings suggest that two or more mechanisms may be involved in these experiments.
Investigation of apoptotic markers in co-infected gastric epithelial cell lines

It is well reported that apoptotic genes are altered with H. pylori and EBV infection in gastric epithelial cell lines individually; however, studies on effect of coinfection on apoptotic genes have been modest [49]. Therefore, to identify the apoptotic genes crucial during coinfection, twelve apoptotic genes were studied that were specific for GC, whose primers have been listed in (Table 2) [50]. Their expression levels were evaluated at a time interval of 12 and $24 \mathrm{~h}$ of incubation. However, to determine the early apoptotic marker, $12 \mathrm{~h}$ was chosen as a time point to proceed with the further investigation of gene expression. The apoptotic genes such as APAF, BIK, FASL, and BAX were found to be significantly down-regulated at $24 \mathrm{~h}$, which implies their potential role in cell proliferation (Fig. 5).

\section{Discussion}

$H$. pylori usually infect during childhood, where its site of residence is the stomach for decades, causing GC, peptic ulcer, and gastritis. This bacteria is known to infect half of the world population [51].

This study includes $H$. pylori isolates from central India for the detection of the early development of GC. Consistent with previous reports, morphological changes were observed due to bacterial infection, which supports aggressive cell proliferation [52]. CagA $+H$. pylori infection in AGS cells causes a hummingbird phenotype by dephosphorylation of vinculin. Hence, vinculin may be one of the reasons for the morphological changes [53]. But as the coinfection resulted in a different morphology, there might be other gene involvement as well. This study demonstrates morphological changes in AGS cells infected with bacteria followed by EBV coinfection. In the co-infected cells, the invasive form was observed at $12 \mathrm{~h}$ compared to a previous study in which they were observed at $24 \mathrm{~h}$ [54]. These morphological changes may be associated with the possible role of EBV and $H$. pylori co-infection in early cell transformation in the gastric epithelial cell line.

Further, we were able to quantify the tapering ends by infecting the cells with bacteria at different time intervals. After $12 \mathrm{~h}$ incubation of co-infected cells, a remarkable elongation of tapering ends of cells was observed.

In this study, $12 \mathrm{~h}$ seems to be a potential time interval to evaluate the effect of EBV on the cells infected with bacteria. These co-cultured AGS cells with $H$. pylori strains and EBV showed an increased number of hummingbird-like cells. This phenotype is considered to promote scattering and spreading of cells, which may be important in carcinogenesis $[50,55]$. But to the best of our knowledge, no such study for length quantification has been done previously for this purpose. 

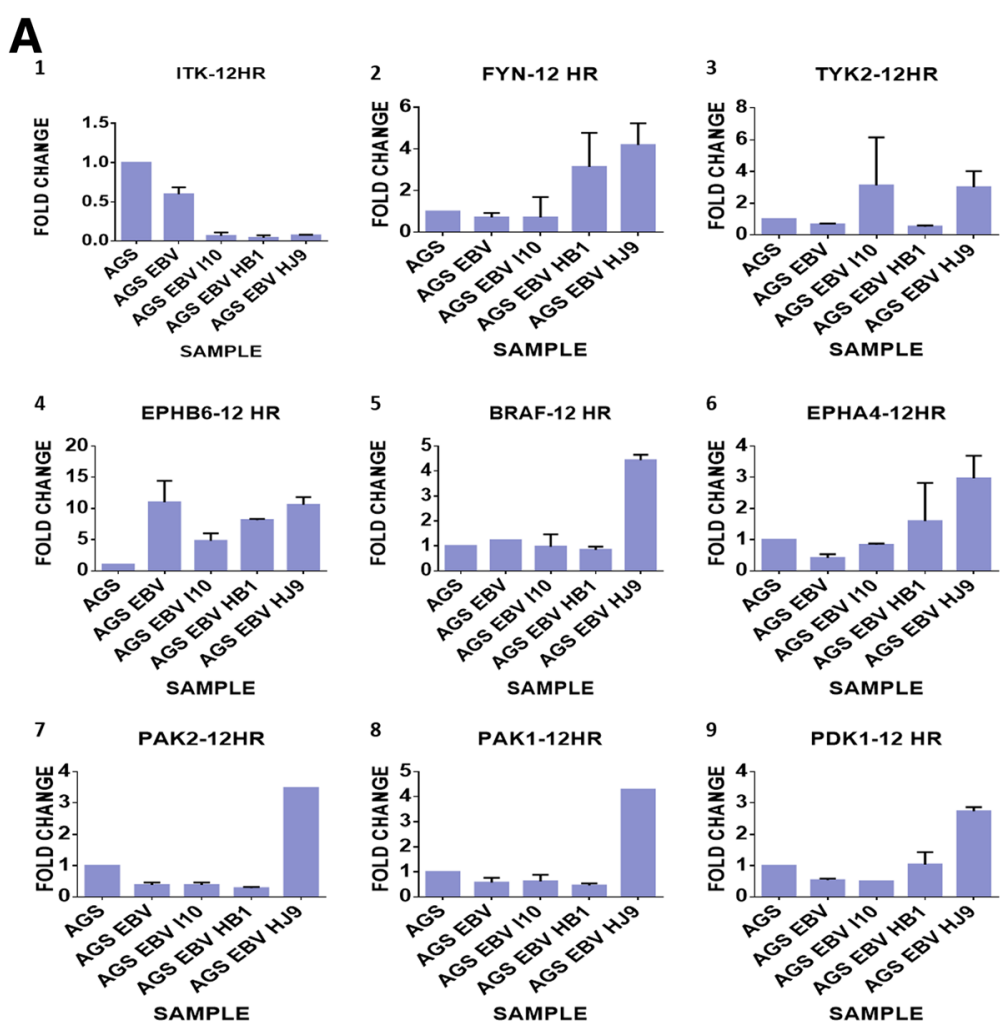

B
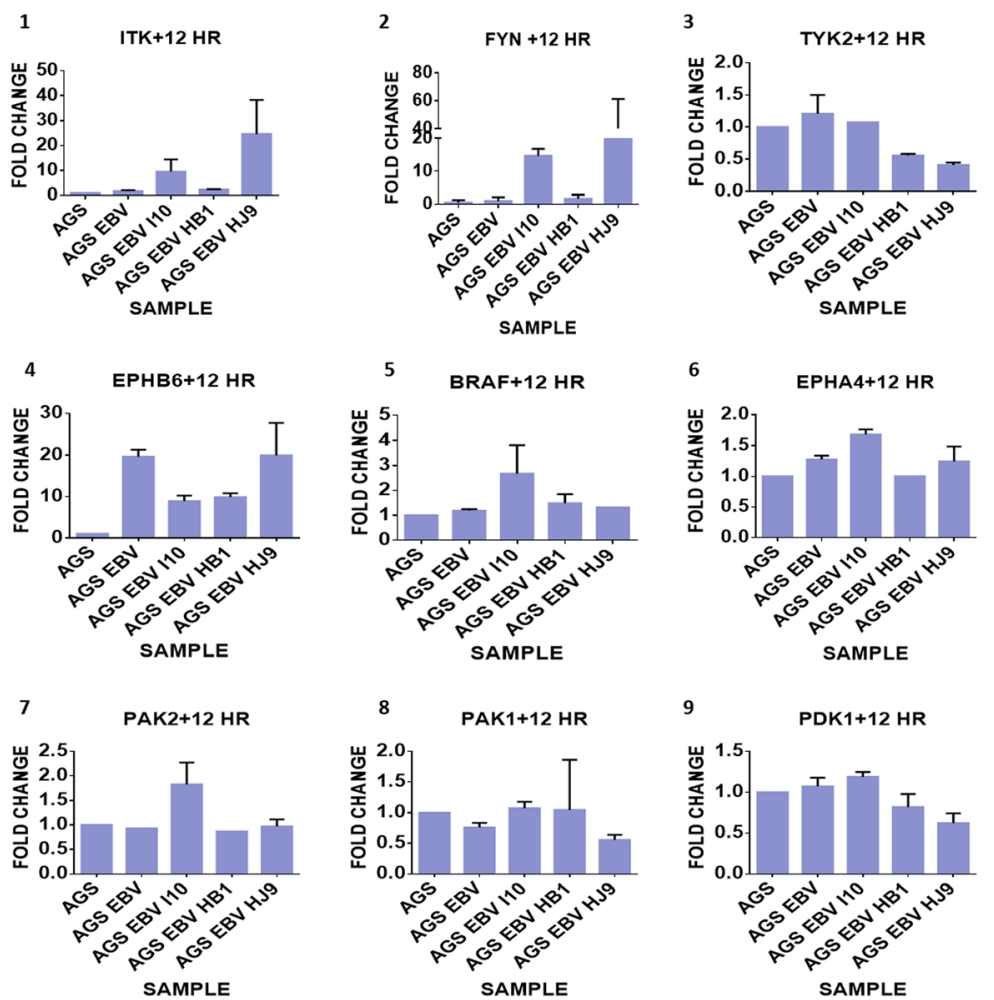

Fig. 4 Assessment of kinase expression through the secretory and adhesive mechanism of bacteria. Gene's expression was shown with a direct and indirect approach at different time points. $\mathbf{a}, \mathbf{b}$ at $12 \mathrm{~h}$. Where " + " indicated experiment performed with insert, i.e., indirect approach and "-" indicates experiment performed without an insert, i.e., direct approach 


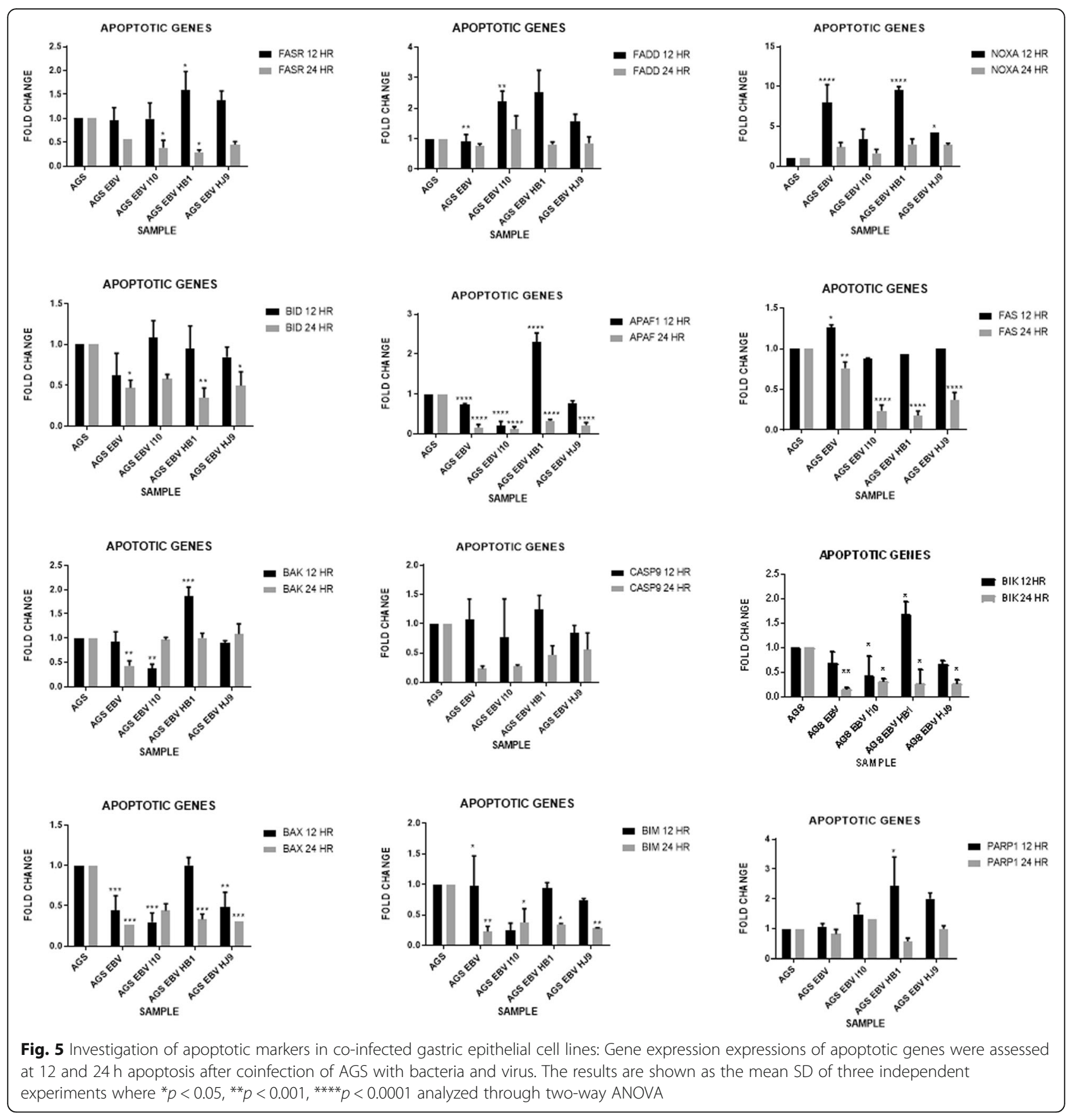

As per our knowledge, this is the first report to demonstrate the differential expression of kinase in coinfected cells using two different approaches, i.e., with transwell inserts (indirect approach) and without transwell (direct approach). With indirect and direct approaches, we aimed to identify the most affected kinase at various time intervals of 12,24 , and $36 \mathrm{~h}$, respectively. The TYK2 and EPHB6 gene were found to be upregulated by adherence of bacteria to the cells in the presence of EBV, whereas secretory proteins of bacteria up-regulate ITK and FYN expression in the presence of
EBV. Though, the expression of genes varies with infection of AGS with EBV, EBV-I10, EBV-HB1, and EBVHJ9, respectively. Moreover, in the direct approach, the ITK gene showed similar down-regulation in the coinfection of AGS with EBV- I10, EBV-HB1, and EBV-HJ9. In contrast, the TYK2 gene showed significant upregulation in comparison to I10 and HJ9 co-infected cells than in infection with EBV or EBV-HB1 only. In $12 \mathrm{~h}$, EPHB6 gene transcript also showed a significant increase in the expression in all co-infected cells. However, the EPHB6 gene showed the highest expression in EBV-HJ9 co- 
infected cells. Similar results were observed with the FYN gene at $24 \mathrm{~h}$. Hence, our findings suggest that TYK2, EPHB6, and FYN can be used for an early prognosis for GC. With the Indirect approach, the ITK gene showed a remarkably significant increase in all infection. In contrast, cells infected with EBV alone showed the highest expression, in comparison to EBV-I10, EBV$\mathrm{HB1}$, and EBV-HJ9 whose expression were significantly increased. An earlier study conducted on breast cancer cells (MCF-7) found that FYN gene expression was higher at 24h [56]. Moreover, the expression of TYK2 and ITK was increased in gastric tissue samples [57]. EphB6, an Eph receptor that doesn't have tyrosine kinase activity, was reported to be expressed in some human cancers. Ephb6 with APC mutation is found to be overexpressed in colorectal cancer [16]. Also, reports have suggested that these kinases may have a role in gastric cancer progression [58].

A similar trend was observed in the FYN gene with the exception of expression in EBV-HJ9, which was reduced in comparison with EBV-I10. Contrarily, in EPHB6, considerable up-regulation was observed in all cases. Hence, when the secretory pathway of $H$. pylori is concerned, ITK, FYN, and EPHB6 can be investigated thoroughly for further studies.

Moreover, $H$. pylori consist of various genes that contribute to enhancing its infection, such as T4SS-pilus localized protein CagA, vacuolation causing secretory protein VacA and outer membrane protein BabA. $\mathrm{CagA}+H$. pylori strain increases the risk of distal GC as it uses the integrin receptor present on the host's cells for its entry in the cells [59]. CagA bridges the T4SS to integrin $\alpha 5 \beta 1$ on host cells, which activates the SRC and focal adhesion kinase, which ensures that CagA is phosphorylated at the site of infection [40]. VacA is a secretory protein that causes vacuolation in cultured epithelial cells. VacA binds to integrin $\beta 2$ and blocks interleukin-2 mediated signaling, which causes downregulation of the $\mathrm{Ca} 2+-$ dependent phosphatase calcineurin and inhibits antigen-dependent proliferation of transformed T cells [60]. Eventually, $H$. pylori interfere with tyrosine kinase, Crk, GTPase, and MAP kinase signaling leading to peptic ulcer, gastritis, and GC [61]. Although the site of the residence of $H$. pylori remains to be within the semi-permeable mucous gel layer of stomach facing towards the apical surface of gastric epithelial cells, about $20 \%$ of the bacteria is known to bind with the epithelium [62]. When genome analysis of $H$. pylori strains was done, a very high proportion of protein-encoding for the open reading frame was identified in the outer and inner membrane of bacterium which is known as outer membrane proteins (omPs) such as BabA which has a role in increased mucosal inflammation, atrophy and severe gastric injury $[63,64]$.

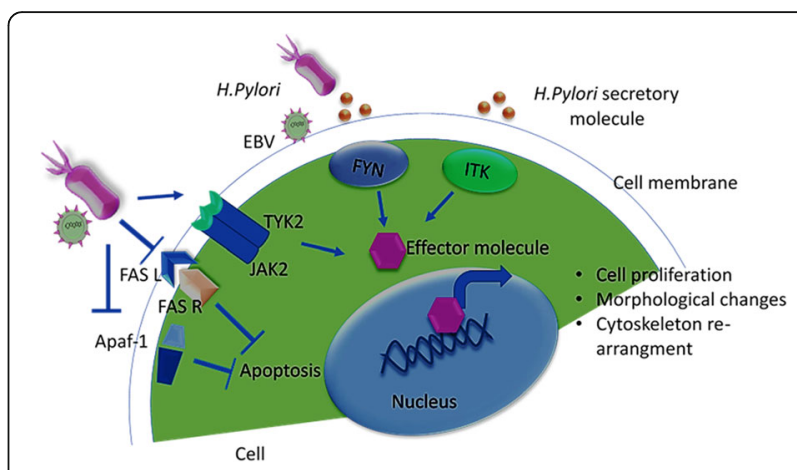

Fig. 6 Graphical abstract of the experimental outcome in the report. H. pylori secretory molecule activates two kinases FYN and ITK, which may activate the effector molecule leading to the nucleus for cell proliferation, morphological changes, and cytoskeleton

rearrangement. $H$. pylori adherence activates TYK2 kinase and inhibits apoptotic genes like FASL, FASR, and APAF-1, which contribute to cell proliferation

Importantly, apoptosis is a regulatory action taken by the cell for cell replacement and damaged cell removal, which can be characterized by chromatin condensation, cell shrinkage, and formation of apoptotic bodies [65]. This process is the result of the extrinsic pathway (extracellular stress) and the intrinsic pathway (intracellular stress) [66]. The death receptor is located at the cell surface, such as Fas/Fas ligand, and is induced by extracellular stress. In comparison, the intrinsic pathway is induced mainly through intracellular stress, which is associated with mitochondria, for example, APAF- 1 and $\mathrm{Bcl} 2$ family [67]. To explore the expression of apoptotic genes through the direct approach, we selected nine apoptotic genes that have been associated with GC. Our experiment found that apoptotic genes, namely APAF-1, BIK, FASL, and BAX, were significantly down-regulated at $24 \mathrm{~h}$ (Fig. 6). Earlier reports suggested that apoptotic genes like APAF-1, Bcl-2, $\mathrm{BAX}$, and Bcl-2 family were found to be up-regulated in gastric cancer tissues [50, 67]. Experiments performed with $H$. pylori in epithelial cell background also demonstrated the expressional differences for APAF-1, Fas-Fas ligand, and $\mathrm{Bcl}-2$ related genes (Bcl-2, BAX, and BAK) genes at $48 \mathrm{~h}$ [68]. Furthermore, based on the experiments performed in the report, a comprehensive representation of the outcome of experiments is diagrammatically illustrated in Fig. 6, where the effect of direct and indirect coinfection in kinase and apoptosis-related signaling pathway is diagrammatically represented.

\section{Conclusion}

Our study uses clinical $H$. pylori isolates along with reference strain to find its phenomenal changes in gastric epithelial cells along with EBV. The remarkable effect of coinfection on morphological changes found to be in 12 $\mathrm{h}$ intervals on implementing quantification of tapering 
ends. This study also demonstrated the kinase and apoptotic genes that might be affected in co-infected cells through direct and indirect approaches. Where ITK, EPHB6, TYK2, and FYN kinase are highly expressed kinase genes and APAF, BIK, FASL, and BAX are the significantly down-regulated apoptotic genes. ITK and TYK2 are receptor tyrosine kinase, which is specifically involved in cellular differentiation, survival, and proliferation and contains the conserved domain of Ig-domains. In stark contrast, non-receptor tyrosine kinase-like FYN, essential for enzyme regulation and substrate identification, was found to be up-regulated by direct dual infection. Hence, their downstream interlinked pathway can provide a potential strategy to understand the progression of GC. However, we do consider the fact that the number of strains used that were isolated from the patients is limited, and further investigation is required for drawing a more consequential conclusion.

\section{Supplementary information}

Supplementary information accompanies this paper at https://doi.org/10. 1186/s12885-020-07377-0.

\section{Additional file 1.}

\section{Abbreviations}

GC: Gastric cancer; H. pylori: Helicobacter pylori; EBV: Epstein barr virus; BRAF1: B-Raf proto-oncogene, serine/threonine kinase; ITK: Interleukin-2inducible T-cell kinase; TYK2: Tyrosine kinase 2; FYN: Tyrosine-protein kinase Fyn; PAK1: P21 protein (Cdc42/Rac)-activated kinase 1; PAK2: P21 protein (Cdc42/Rac)-activated kinase 2; PDK1: Pyruvate dehydrogenase kinase1; EPHA4: Ephrin type-A receptor 4 precursor; EPHB6: Ephrin type-B receptor 6 precursor; AKT3: AKT Serine/Threonine Kinase 3; SRC: Proto-oncogene tyrosine-protein kinase Sarcoma; YES: Cellular homolog of the Yamaguchi sarcoma virus oncogene; mTOR: The mechanistic target of rapamycin; JAK2: Janus kinase 2; MET: Hepatocyte growth factor receptor; FGFR2: Fibroblast Growth Factor Receptor 4; Raf: Raf-1 proto-oncogene, serine/threonine kinase; FGFR4: Fibroblast Growth Factor Receptor 4; ROR2: Receptor Tyrosine Kinase Like Orphan Receptor 2; ERBB4: Erb-B2 Receptor Tyrosine Kinase 4; ERBB2: Erb-B2 Receptor Tyrosine Kinase 2

\section{Acknowledgments}

We appreciate Dr. Asish Kumar Mukhopadhyay (National Institute of Cholera and Enteric Diseases, Kolkata) for providing the Helicobacter pylori strain I10. Ms. Charu Sonkar would like to express her sincere gratitude to CSIR, India, for her doctoral fellowship (09/1022(0035)/2017-EMR-I. We also appreciate the Sophisticated Instrumentation Centre, IIT Indore for Confocal microscopy, and LC-MS facility. We also appreciate Dr. Erle S Robertson (University of Pennsylvania, USA) for providing us with HEK 293 T EBV BAC cell, which consistently expressed Epstein Barr Virus (EBV) genome. We would like to thank Dr. Rajeev Kaul for proof read of the manuscript.

\section{Authors' contributions \\ $\mathrm{HCJ}$ coordinated the project and designed experiments. CS carried out experiments, and TV performed Gram's staining experiments for the H. pylori strains. HCJ and CS analyzed data and wrote the manuscript. Samples of human gastric biopsy and gastric juice were provided by DC and AJ. All authors revised, approved and proof read the manuscript.}

\section{Funding}

This project was supported by the Council of Scientific and Industrial Research grant no, (09/1022(0035)/2017-EMR-I) for financially supporting this project. This project is financially supported by the Department of Science and Technology as Ramanujan fellowship grant no. SB/S2/RJN-132/20/5 \&
DST-EMR: EMR/2017/001637. The authors declare that they have no conflict of interest. The funding bodies had no role in study design, collection, analysis, interpretation of data, writing the manuscript, or decision to publish.

\section{Availability of data and materials}

All-important data are presented in the manuscript or supplementary figures. Some other supporting information that may not be crucial or affecting result interpretation is not included. Moreover, these data can be available from the corresponding author on a reasonable request.

\section{Ethics approval and consent to participate}

The protocol for the present study was approved by the ethics committee of the Indian Institute of Technology Indore, as well as Choithram Hospital and Research Centre, Indore (approval number FD090), and all procedures were performed by following the revised declaration of Helsinki 2000.

\section{Consent for publication}

Not applicable.

\section{Competing interests}

The authors declare that they have no competing interests.

\section{Author details}

${ }^{1}$ The Discipline of Biosciences and Biomedical Engineering, Indian Institute of Technology Indore, Room no. 302, School Building, IIT Indore, Khandwa Road, Simrol, Indore 453552, India. ${ }^{2}$ Choithram Hospital and Research Centre Indore, Indore, Madhya Pradesh, India.

Received: 6 May 2020 Accepted: 3 September 2020

Published online: 29 September 2020

\section{References}

1. Van Cutsem E, Sagaert X, Topal B, Haustermans K, Prenen H. Gastric cancer. Lancet. 2016;388:2654-64.

2. Wang F, Meng W, Wang B, Qiao L. Helicobacter pylori-induced gastric inflammation and gastric cancer. Cancer Letters. 2014;345:196-202.

3. Prabhu SR, Amrapurkar AD, Amrapurkar DN. Role of Helicobacter pylori in gastric carcinoma. Natl Med J India. 1995;8:3.

4. Cover TL. Helicobacter pylori diversity and gastric Cancer risk. Gastric Cancer. 2016;7:1-9.

5. Dong Z, Cui H. Epigenetic modulation of metabolism in glioblastoma. Semin Cancer Biol. 2019;57:45-51.

6. Biology C, Sokolova O, Vieth M, Gnad T, Bozko PM, Naumann M. The international journal of biochemistry helicobacter pylori promotes eukaryotic protein translation by activating phosphatidylinositol 3 kinase / mTOR. Int J Biochem Cell Biol. 2014:55:157-63.

7. Xie YG, Yu Y, Hou LK, Wang X, Zhang B, Cao XC. FYN promotes breast cancer progression through epithelial-mesenchymal transition. Oncol Rep. 2016;36:1000-6.

8. Chen Y-C, Wang Y, Li J-Y, Xu W-R, Zhang Y-L. H pylori stimulates proliferation of gastric cancer cells through activating mitogen-activated protein kinase cascade. World J Gastroenterol. 2006;12:5972-7.

9. Hatakeyama M. Helicobacter pylori and gastric carcinogenesis. J Gastroenterol. 2009;44:239-48.

10. Hunter T. Discovering the first tyrosine kinase. Proc Natl Acad Sci U S A. 2015;112:7877-82.

11. McDuffie NG. Protein kinase Collett MS, Erikson RL. Protein kinase activity associated with the avian sarcoma virus src gene product. Proc Natl Acad Sci USA. 1978;75:2021-4.

12. Jacobs C, Rübsamen $\mathrm{H}$. Expression of pp60c-src Protein Kinase in Adult and Fetal Human Tissue: High Activities in Some Sarcomas and Mammary Carcinomas. Cancer Res. 1983;43:1696.

13. Esau D. Viral Causes of Lymphoma: The History of Epstein-Barr Virus and Human T-Lymphotropic Virus 1. Virology: Research and Treatment. 2017;8: $1178122 \times 1773177$.

14. Morales-Sanchez A, Fuentes-Panana EM. Epstein-Barr virus-associated gastric Cancer and potential mechanisms of Oncogenesis. Curr Cancer Drug Targets. 2016;17:534-54.

15. Matsusaka K, Kaneda A, Nagae G, Ushiku T, Kikuchi Y, Hino R, et al. Classification of Epstein-Barr virus-positive gastric cancers by definition of DNA methylation epigenotypes. Cancer Res. 2011;71:7187-97. 
16. Liu J, Xu B, Xu G, Zhang X, Yang X, Wang J. Reduced EphB6 protein in gastric carcinoma and associated lymph nodes suggests EphB6 as a gastric tumor and metastasis inhibitor. Cancer biomarkers : section A of Disease markers. 2017:19:241-248.

17. Khetpal N, Ali S, Kumar R, Rashid MU, Ahmad S. The Clinical and Biological Significance of Tyrosine Kinases in Gastric Cancer. In: Nagaraju GP, editor. Role of Tyrosine Kinases in Gastrointestinal Malignancies. Singapore: Springer; 2018;29-56.

18. Miyazaki K, Inokuchi M, Takagi Y, Kato K, Kojima K, Sugihara K. EphA4 is a prognostic factor in gastric cancer. BMC Clin Pathol. 2013:13:19.

19. Gao C, Ma T, Pang L, Xie R. Activation of P21-activated protein kinase 2 is an independent prognostic predictor for patients with gastric cancer. Diagn Pathol. 2014;9:1-6.

20. Raimondi C, Falasca M. Targeting PDK1 in Cancer. CMC. 2011;18:2763-9.

21. Xu J, Gong L, Qian Z, Song G, Liu J. ERBB4 promotes the proliferation of gastric cancer cells via the PI3K/Akt signaling pathway. Oncol Rep. 2018;39:2892-8.

22. Lin W, Kao H-W, Robinson D, Kung H-J, Wu C-W, Chen H-C. Tyrosine kinases and gastric cancer. Oncogene. 2000;19:5680-9.

23. Ye $Y$, Jiang $D$, Li J, Wang M, Han C, Zhang $X$, et al. Silencing of FGFR4 could influence the biological features of gastric cancer cells and its therapeutic value in gastric cancer. Tumor Biol. 2016;37:3185-95.

24. Yan L, Du Q, Yao J, Liu R. ROR2 inhibits the proliferation of gastric carcinoma cells via activation of non-canonical Wnt signaling. Exp Ther Med. 2016;12:4128-34.

25. Sousa H, Pinto-Correia AL, Medeiros R, Dinis-Ribeiro M. Epstein-Barr virus is associated with gastric carcinoma: the question is what is the significance? World J Gastroenterol. 2008;14:4347-51.

26. Cárdenas-Mondragón MG, Carreón-Talavera R, Camorlinga-Ponce M, Gomez-Delgado A, Torres J, Fuentes-Pananá EM. Epstein Barr Virus and Helicobacter pylori Co-Infection Are Positively Associated with Severe Gastritis in Pediatric Patients. PLoS ONE. 2013;8:e62850.

27. Pandey S, Jha HC, Shukla SK, Shirley MK, Robertson ES. Epigenetic Regulation of Tumor Suppressors by Helicobacter pylori Enhances EBVInduced Proliferation of Gastric Epithelial Cells. mBio. 2018;9:e00649-18.

28. Shukla SK, Jha HC, El-Naccache DW, Robertson ES. An EBV recombinant deleted for residues 130-159 in EBNA3C can deregulate p53/Mdm2 and Cyclin D1/CDK6 which results in apoptosis and reduced cell proliferation. Oncotarget. 2016;7:18116-34.

29. Halder S, Murakami M, Verma SC, Kumar P, Yi F, Robertson ES. Early events associated with infection of Epstein-Barr virus infection of primary B-cells. PLoS One. 2009;4:e7214.

30. Boudreault S, Armero VES, Scott MS, Perreault J-P, Bisaillon M. The EpsteinBarr virus EBNA1 protein modulates the alternative splicing of cellular genes. Virol J. 2019;16:29.

31. Coleman CB, Wohlford EM, Smith NA, King CA, Ritchie JA, Baresel PC, et al. Epstein-Barr virus type 2 latently infects T cells, inducing an atypical activation characterized by expression of Lymphotactic cytokines. J Virol. 2015;89:2301-12.

32. Shannon-Lowe C, Adland E, Bell Al, Delecluse H-J, Rickinson AB, Rowe M. Features distinguishing Epstein-Barr virus infections of epithelial cells and $B$ cells: viral genome expression, genome maintenance, and genome amplification. J Virol. 2009:83:7749-60

33. Lay M-U, Lucas RM, Ratnamohan M, Taylor J, Ponsonby A-L, Dwyer DE, et al. Measurement of Epstein-Barr virus DNA load using a novel quantification standard containing two EBV DNA targets and SYBR green I dye. Virol J. 2010;7:252.

34. Heawchaiyaphum C, lizasa H, Ekalaksananan T, Burassakarn A, Kiyono T, Kanehiro $Y$, et al. Epstein-Barr virus infection of Oral squamous cells. Microorganisms. 2020;8:419.

35. Kashyap D, Baral B, Verma TP, Sonkar C, Chatterji D, Jain AK, et al. Oral rinses in growth inhibition and treatment of helicobacter pylori infection. BMC Microbiol. 2020;20:45.

36. Kim G, Kim T-H, Kang M-J, Choi J-A, Pack D-Y, Lee I-R, et al. Inhibitory effect of withaferin a on helicobacter pylori-induced IL-8 production and NF-KB activation in gastric epithelial cells. Mol Med Rep. 2016;13:967-72.

37. Gryko M, Pryczynicz A, Zareba K, Kędra B, Kemona A, Guzińska-Ustymowicz K. The Expression of Bcl-2 and BID in Gastric Cancer Cells. Journal of Immunology Research. 2014;2014:1-5.

38. Foglieni C, Scabini S, Belloni D, Broccolo F, Lusso P, Malnati MS, et al. Productive infection of HUVEC by HHV-8 is associated with changes compatible with angiogenic transformations. Eur J Histochem. 2005;49:273-84.
39. Safari F, Jodeiry Zaer S. Evaluation of cell- morphological changes by helicobacter pylori CagA and Pragmin in AGS human gastric carcinoma cells. Gene Cell Tissue. 2017;4:0-3.

40. Selbach M, Moese S, Hurwitz R, Hauck CR, Meyer TF, Backert S. The helicobacter pylori CagA protein induces cortactin dephosphorylation and actin rearrangement by c-Src inactivation. EMBO J. 2003;22:515-28.

41. Roose J, Polevoy GA, Clevers H, Embo J. Letters To Nature. Nature. 1998;395: 521-5.

42. Selbach M, Moese S, Backert S, Jungblut PR, Meyer TF. The helicobacter pylori CagA protein induces tyrosine dephosphorylation of ezrin. Proteomics. 2004:4:2961-8.

43. Basque J-R, Chénard M, Chailler P, Ménard D. Gastric cancer cell lines as models to study human digestive functions. J Cell Biochem. 2001;81:241-51.

44. Oleastro M, Ménard A. The role of helicobacter pylori outer membrane proteins in adherence and pathogenesis. Biology. 2013;2:1110-34.

45. Bodger $\mathrm{K}$, Crabtree JE. Helicobacter pylori and gastric inflammation. Br Med Bull. 1998;54:139-50.

46. Kim N, Weeks DL, Shin JM, Scott DR, Young MK, Sachs G. Proteins released by helicobacter pylori in vitro. J Bacteriol. 2002;184:6155-62.

47. Liersch-Löhn B, Slavova N, Buhr HJ, Bennani-Baiti IM. Differential protein expression and oncogenic gene network link tyrosine kinase ephrin B4 receptor to aggressive gastric and gastroesophageal junction cancers: EPHB4 associates to aggressive gastroesophageal cancers. Int J Cancer. 2016;138:1220-31.

48. Kwok T, Backert S, Schwarz H, Berger J, Meyer TF. Specific entry of helicobacter pylori into cultured gastric epithelial cells via a zipper-like mechanism. Infect Immun. 2002;70:2108-20.

49. Shinozaki-Ushiku A, Kunita A, Fukayama M. Update on epstein-barr virus and gastric cancer (review). Int J Oncol. 2015;46:1421-34.

50. Guo J Qiang, Li S jie, Guo G xiao. Long noncoding RNA AFAP1-AS1 promotes cell proliferation and apoptosis of gastric Cancer cells via PTEN/pAKT pathway. Dig Dis Sci. 2017;62:2004-10.

51. Montecucco C, Rappuoli R. Living dangerously: how helicobacter pylori survives in the human stomach. Nat Rev Mol Cell Biol. 2001;2:457-66.

52. Ciufo DM, Cannon JS, Poole L, Wu FY, Murray P, Ambinder RF, et al. Spindle cell conversion by Kaposi's sarcoma-associated Herpesvirus: formation of colonies and plaques with mixed lytic and latent gene expression in infected primary dermal microvascular endothelial cell cultures. J Virol. 2001;75:5614-26.

53. Moese S, Selbach M, Brinkmann V, Karlas A, Haimovich B, Backert S, et al. The helicobacter pylori CagA protein disrupts matrix adhesion of gastric epithelial cells by dephosphorylation of vinculin. Cell Microbiol. 2007;9:1148-61.

54. Stein M, Bagnoli F, Halenbeck R, Rappuoli R, Fantl WJ, Covacci A. C-Src/Lyn kinases activate helicobacter pylori CagA through tyrosine phosphorylation of the EPIYA motifs. Mol Microbiol. 2002;43:971-80.

55. Argent RH, Kidd M, Owen RJ, Thomas RJ, Limb MC, Atherton JC. Determinants and consequences of different levels of CagA phosphorylation for clinical isolates of helicobacter pylori. Gastroenterology. 2004;127:514-23.

56. Lee GH, Yoo KC, An Y, Lee HJ, Lee M, Uddin N, et al. FYN promotes mesenchymal phenotypes of basal type breast cancer cells through STAT5/ NOTCH2 signaling node. Oncogene. 2018;37:1857-68.

57. Wu C, Li AF, Chi C, Huang CL, Shen K, Liu W, et al. Human gastric Cancer kinase profile and prognostic Significance of MKK4 kinase. Am J Pathol. 2007:156:2007-15.

58. Morishita A, Gong J, Masaki T. Targeting receptor tyrosine kinases in gastric cancer. World J Gastroenterol. 2014;20:4536-45.

59. Peek RM, Blaser MJ. Helicobacter pylori and gastrointestinal tract adenocarcinomas. Nat Rev Cancer. 2002;2:28-37.

60. Gebert B, Fischer W, Weiss E, Hoffmann R, Haas R. Helicobacter pylori vacuolating cytotoxin inhibits T lymphocyte activation. Science. 2003;301: 1099-102.

61. Brandt S, Shafikhani S, Balachandran P, Jin S, Hartig R, König W, et al. Use of a novel coinfection system reveals a role for Rac1, H-Ras, and Crkll phosphorylation in helicobacter pylori-induced host cell actin cytoskeletal rearrangements. FEMS Immunol Med Microbiol. 2007;50:190-205.

62. Tomb JF, White O, Kerlavage AR, Clayton RA, Sutton GG, Flelschmann RD, et al. Erratum: the complete genome sequence of the gastric pathogen helicobacter pylori. Nature. 1997;389:412. 
63. Alm RA, Ling LSL, Moir DT, King BL, Brown ED, Doig PC, et al. Genomicsequence comparison of two unrelated isolates of the human gastric pathogen helicobacter pylori. Nature. 1999;397:176-80.

64. Yamaoka Y. Roles of helicobacter pylori BabA in gastroduodenal pathogenesis. World J Gastroenterol. 2008;14:4265-72.

65. Chandra J, Samali A, Orrenius S. Triggering and modulation of apoptosis by oxidative stress. Free Radic Biol Med. 2000;29:323-33.

66. Wang $\mathrm{S}-\mathrm{Q}$, Wang $\mathrm{C}$, Chang L-M, Zhou K-R, Wang J-W, Ke Y, et al. Geridonin and paclitaxel act synergistically to inhibit the proliferation of gastric cancer cells through ROS-mediated regulation of the PTEN/PI3K/Akt pathway. Oncotarget. 2016;7:72990-3002

67. Kale J, Osterlund EJ, Andrews DW. BCL-2 family proteins: changing partners in the dance towards death. Cell Death Differ. 2018;25:65-80.

68. Choi IJ, Kim JS, Kim JM, Jung HC, Song IS. Effect of inhibition of extracellular signal-regulated kinase 1 and 2 pathway on apoptosis and bcl-2 expression in helicobacter pylori-infected AGS cells. Infect Immun. 2003;71:830-7.

\section{Publisher's Note}

Springer Nature remains neutral with regard to jurisdictional claims in published maps and institutional affiliations.

Ready to submit your research? Choose BMC and benefit from:

- fast, convenient online submission

- thorough peer review by experienced researchers in your field

- rapid publication on acceptance

- support for research data, including large and complex data types

- gold Open Access which fosters wider collaboration and increased citations

- maximum visibility for your research: over $100 \mathrm{M}$ website views per year

At BMC, research is always in progress.

Learn more biomedcentral.com/submissions 